DOI: https://doi.org/10.34069/AI/2021.43.07.20

How to Cite:

Khyzhniak, Y., Rasiuk, E., Chabaniuk, V., Myshkov, Y., \& Davydiuk, V. (2021). Scientific genesis of operational and search measures to combat intentional homicide by the criminal police. Amazonia Investiga, 10(43), 200-208. https://doi.org/10.34069/AI/2021.43.07.20

\title{
Scientific genesis of operational and search measures to combat intentional homicide by the criminal police
}

\author{
Науковий генезис оперативно-розшукової протидії умисним вбивствам \\ підрозділами кримінальної поліції
}

Received: July 10, 2021

\begin{abstract}
The aim of the article is to consider the scientific genesis of the problem of operational and investigative measures to combat intentional homicide by criminal police units. Subject of research is the stages on development of scientific knowledge on the issue under investigation. Methodology: In the course of the research the following methods are used: analysis and synthesis method, dialectical method, logical and semantic method, historical and legal method, legal modeling method. Research results: The state of scientific researches on the problem of crime prevention by the criminal police in general and intentional homicide in particular was examined. Practical consequences: In the course of the research, the development of scientific knowledge on the prevention of intentional homicide by criminal police units was gradually considered. Value / originality: It is the first study dedicated to the development of the history of prevention of intentional homicide by criminal police units in Ukraine.
\end{abstract}

Accepted: August 18, 2021

Written by:

Yevhen Khyzhniak $^{73}$

https://orcid.org/0000-0001-8263-0353

Eduard Rasiuk ${ }^{74}$

https://orcid.org/0000-0003-4065-5266

Vadim Chabaniuk ${ }^{75}$

https://orcid.org/0000-0002-1986-9481

Yaroslav Myshkov ${ }^{76}$

https://orcid.org/0000-0001-6160-1983

Vadym Davydiuk ${ }^{77}$

https://orcid.org/0000-0003-4068-9909

\footnotetext{
${ }^{73}$ Ph.D. in Law, associate professor, Associate Professor of the Department of Criminalistics of the National University "Odessa Law Academy", Ukraine.

${ }^{74} \mathrm{PhD}$ in Law, Associate Professor, Professor of the Department of Criminology and Penal Enforcement Law of the National Academy of Internal Affairs, Ukraine.

${ }^{75} \mathrm{PhD}$ in Law, Associate Professor, Asociate Professor of the Department of Criminal Law of the National Academy of Internal Affairs, Ukraine.

${ }^{76} \mathrm{Ph} . \mathrm{D}$ in Law, Associate Professor of the Department of Criminalistics of Yaroslav Mudryi National Law University, Ukraine.

${ }^{77}$ Doctor of science of Law, Doctor of Law, Professor at the Department of Law of Dnipro Humanities University, Ukraine.
} 


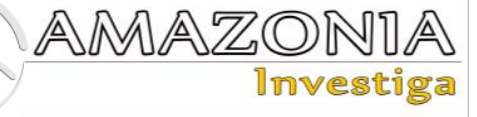

Key words: scientific genesis, intentional homicide, prevention, criminal police units, historical development.

\section{Introduction}

According to the Art. 3 of the Constitution of Ukraine (No. 254k/96-VR, 1996) an individual, his life and health, honour and dignity, inviolability and security shall be recognised in Ukraine as the highest social value. No one shall be arbitrarily deprived of life. Protection of human life shall be the duty of the State. (Article 27).

Recognizing this task as one of the top priorities, the legislator entrusted its implementation to law enforcement agencies, giving them the appropriate powers. For example, the main tasks of the National Police as the main law enforcement body are the protection of human rights and freedoms, the interests of society and the State, as well as the fight against crime. To perform these and other tasks, police officers, in particular, carry out proactive measures aimed at preventing the commission of offenses.

Preventive activity of law enforcement agencies is considered to be one of the leading functions of the system, which ensures the achievement of real results in the fight against crime. Based on the tasks facing the criminal police units and their inherent operational and investigative competence, they are called to carry out activities to prevent criminal offenses through the active use of operational and investigative prevention measures.

Although many scientists have examined this issue in their works, but the problem of operational and search prevention of intentional homicide was given little attention, which determined the relevance of our study.

\section{Methodology}

The study used general scientific and special methods of scientific research. Thus, the analysis and synthesis method as well as the logical method were used to develop a holistic view on the institution of intentional homicide prevention.

The dialectical approach makes it possible to know the general laws of social dialectics, to understand the root causes of the reform умисним вбивствам ... підрозділами кримінальної поліції в Україні.

Ключові слова: науковий генезис, умисне вбивство, профілактика, підрозділи кримінальної міліції, історичний розвиток.

processes, the laws of their development. In the case this method helped to examine the problem of operational and investigative measures to combat intentional homicide as a whole.

The method of analyses that studies the object by splitting it into constituent elements, such as parts of the object, its features, properties, relations and considers each of the selected elements separately within a single whole, was useful in investigation of the separate components of the issue under consideration.

Monographic method, which is applied to monitor the views of scientists on a particular issue, made it possible to consider the state of scientific researches concerning this issue.

Logical and semantic method, which helps to define concepts by analyzing their features, the relationship between linguistic expressions and reality, was used to establish the meaning of the concepts of "crime prevention", and "intentional homicide prevention".

With the help of the historical and legal method that can be used when comparing concepts, phenomena and processes within particular historical period, the stages of the development of the institution of intentional homicide prevention were determined.

The use of the legal modeling method made it possible to develop the relevant conclusions.

\section{Literature Review}

Crime prevention has become a widely discussed topic nowadays, as "prevention is better than cure". This institution has been included into the national legislation of a many counties, and studied by a number of scholars.

For example, International Criminal Police Organization (US Department of Justice, 1963) proves that the police combine preventive action with their investigative and law enforcement duties. traditional preventive action stems from police officers' presence. modern preventive 
action tries to reach out to individuals who are liable to become offenders or victims.

Van Dijk and de Waard (1991, p. 483) define crime prevention as the total of all private initiatives and State policies, other than the enforcement of criminal law, aimed at the reduction of damage caused by acts defined as criminal by the State.

Chainey and Ratcliffe (2005) distinguish between the terms 'community safety', 'crime control', 'crime reduction', and 'crime prevention'. According to them crime prevention involves any activity by an individual or group, public or private, which attempts to eliminate crime prior to it occurring or before any additional activity results. By drawing on the public health model, some theorists have distinguished between primary crime prevention (universal), secondary crime prevention (at-risk) and tertiary crime prevention (known offenders).

United Nations Office on Drugs and Crime (2010, pp. 16 - 17) distinguish three levels of crime prevention. Primary prevention refers to programmes or initiatives aimed at those who have never been involved in the criminal justice system. Secondary prevention refers to programmes specifically targeted to children and young people who are identified by the social services, educational or justice systems as being at risk of involvement in crime. Tertiary prevention refers to programmes for those who are in the criminal justice system and/or returning to the community, with the aim of preventing reoffending.

The tasks facing criminal police units in preventing violent crimes are the same for all units and follow from the general tasks of crime prevention. However, the degree of participation of each service or unit, the forms and methods of their work are different depending on the competence (Khyzhniak, Khankevych, Shapovalenko, Shkelebei, \& Yatsyk, 2021, p. 213).

\section{Results and Discussion}

The concept of operational and search measures to investigate intentional homicide in Ukraine originated in the days of Kiev Rus. Thus, in order to catch the criminal, our ancestors used the procedure of "chasing the trail", which consisted of searching for the perpetrator by the representatives of the mining courts "in hot pursuit". The trial began with the bark finding traces of a crime. Cherkaskyi (1928) identified three types of traces in the proceedings of that time: 1) a trace left directly by the offender; 2) a trail left by an animal (for example, a horse used by a criminal); 3) the things left at the crime scene. Of particular importance was the fact that the traces of the crime were fresh, or, as sometimes noted in the acts of the mining courts, "hot", as this significantly contributed to the success of the criminal investigation.

There was no prosecution of a suspected thief or murderer outside the city or community. It was believed that the criminal was where his traces are lost. If the trail was lost on the main road or in the steppe, the search stopped. Otherwise, the person to whom the trail lead was considered a criminal if he "did not led the trail in other direction". If the pursuit of a fugitive on the trail (this was called "pursuit of the trail") was not successful, then the commune, which led to the trail, had to extradite the offender, or be responsible for the crime. In such cases, the commune paid a fine. The same happened to the community if a murdered prince's servant was found on its territory. However, Russkaya Pravda stated that "the community does not pay for the corpse or bones found on its territory, if they do not know the victim and no one has heard about what happened". The "pursuit of the trail" took place with the preservation of ancient ceremonial forms. Anyone who "chased the trail" could demand help from the authorities (Terliuk, 2006).

Later in the history of our State, some other normative acts ware adopted, which directly or indirectly regulated the issue of operational and search measures (for example, the Pskov Charter, Sudebniki 1497 and 1550, the Synodic Code of 1649). However, these documents mainly concerned measures taken in the investigation of thefts.

The first prototype of the body that had the right to carry out operational and search measures to detect crimes, including intentional homicides, was the Chancellery of Secret and Investigative Actions, which was the successor to the Preobrazhensky Chamber, created in 1686 by Peter I to investigate cases of national importance. The Chancellery was empowered to investigate the following categories of cases: crimes against life and health, and the good name of the emperor; treason and riots; other criminal cases. However, due to the small number of employees of this agencie, the latter was engaged exclusively in crimes that encroached on the State system and territorial integrity of the Russian Empire, which at that time included 


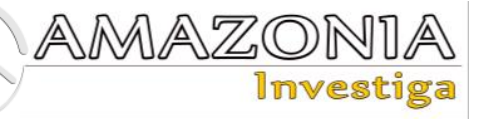

Ukraine (assassination attempts, coup attempts, treasons, schematics cases, bribery and abuse of power on the ground, court intrigues and quarrels, etc.). Besides, the Chancellery had the right to conduct operational and search activities.

Significant increase in crime in large cities in the middle of the $19^{\text {th }}$ century and the lack of effective measures to combat it, forced the government to create in 1866 a detective unit at the St. Petersburg mayor's office, the first head of which was Putilin, who proved to be a talented organizer of the detective activity. Following St. Petersburg, detective units began to be created in other large cities - Kiev, Odessa, Riga, Tiflis, Baku, Moscow, Rostov-on-Don, but a single national criminal investigation system did not exist. Structurally detective departments consisted of four divisions: 1) personal detention; 2) observation; 3) search; 4) the reference and registration bureau, which was the main part of the internal organization of the detective police (Abroskin, 2020, p. 12).

The legal basis for the activities of the police was the Instruction to the ranks of the police of August 09, 1910 (Statehistory, 2011). In accordance with paragraphs $1-2$ of this document, the investigation departments had to covertly investigate and conduct inquiries in the form of prevention, elimination, detection and prosecution of criminal acts of a general criminal nature. In order to carry out these tasks, the branches, through their ranks, have systematic supervision over criminal and vicious elements through covert intelligence and external surveillance.

The instruction recommended a linear principle of work organization, i.e. specialization in certain types of crime. Three categories of specialization were established: 1) murders, robberies, and arson; 2) theft and professional criminal organizations (burglars, horse thieves, pickpockets, shops, railways and others); 3) fraud, counterfeiting, forgery, various scams, smuggling, sale of women in brothels and abroad.

The first attempt to create such a body directly on the territory of our State was made in Kyiv in 1873, where a detective unit was formed as an experiment under the Kyiv City Police. The newly created unit was aimed at: 1) taking measures to prevent murders, robberies, thefts, arson and other crimes in Kyiv; 2) collecting operational information and verification of denunciations; 3) surveillance of persons under supervision, as well as fraudsters and persons engaged in gambling, etc.

Since 1905, the activities of the Kyiv Investigative Police began to be regulated by the Instruction of the Kyiv Investigative Police - the first legal act that not only regulated the general aspects of the organization and activities of the detective department, but also was a universal practical guide for forensic science. According to the Instruction, the police consisted of a search unit whose special task was to register all criminals and suspects, identify the perpetrator through anthropological research, and register drivers, porters, janitors and guards (Chysnikov, 2000, p. 307).

The Instruction, in particular, emphasized that detectives must always act "in complete secrecy and with great caution, ... know everything, see everything" and at the same time try not to be noticed by anyone, to keep the official secret entrusted to them and not tell anyone about the goals and plans of their official actions and generally be restrained and tactful". Noting the role of the secret agency in preventing, detecting and disclosing crimes, the Instruction, in particular, stated: "It is necessary to pass through the filter of inquiry any intelligence information obtained in the case, and those that prove to be credible should form the basis of the inquiry" (Abroskin 2020, p. 15).

Around this time, the first works began to be published, some aspects of which were devoted to the problems of operational and search counteraction to intentional homicides by the relevant police units. However, most of them considered forensic aspects of crime prevention and detection tactics (features of dactyloscopy, ballistic examinations, study of the characteristics of the offender, etc.). It should be noted that the operational and search activities themselves were not considered as a separate science, but were considered an integral part of criminology. Only in the 70 's of the $20^{\text {th }}$ century some scientists began to justify the need for its allocation into an independent area of knowledge. During the same period, the first foundations of the theory of prevention of crimes by law enforcement agencies were laid.

For example, Alieksieiev (1978, p. 166) hypothesized that operational units, using the covert method, also carry out preventive measures that to some extent do not correspond to the traditional organizational and tactical forms of the operational and search activities by law enforcement agencies. 
Zhohin (1962, pp. 34 - 35) identifies the following groups of measures to prevent offenses (including intentional homicides):

a) to prevent the possibility of committing crimes by a person whose conduct indicates the existence of such a danger;

b) to prevent recidivism by those who have served their sentence or who have been released earlier, as well persons referred to collective rehabilitation, parents, etc.;

c) to prevent or suppress crimes under preparation;

d) to eliminate the causes and conditions that objectively make it possible or facilitate the commission.

Besides, the Author proses the classification of preventive measures on their nature and their division into the following types: technical, procedural, organizational, supervisory, operational and public awareness.

The scientific developments of the Soviet scientist Liekar in this area played a significant role in establishing the concept of crime prevention by law enforcement agencies. In his work "Crime Prevention" (1972, pp. 86 - 88), he stressed, in particular, that investigators conducting pre-trial investigations and operatives conducting inquiries do not have a clear idea of the specific nature of the causes crimes, and conditions that contribute to their commission, their differences from each other, the relationship between them, specific areas of manifestation and "mechanism" of action, because they do not yet have scientifically sound developments in tactics and methods of clarifying these causes and conditions. There are no scientific generalizations of positive experience in their detection.

The analysis of the specific operational situation in the territory served by a particular body of internal affairs, finding out what types of crimes are most common, at what time of day and in what places they are committed, establishing the circle of persons who most often commit these crimes, finding out their age, social status, level of education provides extremely interesting and useful data. The proper use of this information allows eliminating the gaps and shortcomings in the work, increasing the effectiveness of crime prevention measures. Gathering reliable, objective and complete information about the causes and conditions creates the necessary prerequisites for the implementation of general crime prevention. It should be followed by timely implementation of effective measures to eliminate the identified causes and conditions.

It is believed that the first scientist who introduced the concept of "operational and search prevention" into scientific circulation was Samoilov (1982, p. 14). In his opinion, it is the activity of operational units regulated by departmental regulations, aimed at carrying out individual preventive measures against persons who can be expected to commit the offenses.

The most detailed theoretical and applied issues of operational and search prevention as an independent organizational and tactical form of operational and investigative activities were proposed by Ovchynskyi (1982, pp. 6 -7), who considered operational and search prevention as the set of measures carried out using means and methods of operational and search activities, aimed at solving the following tasks:

persistent awareness of the criminogenic part of the population;

timely receipt of information on trends in the behavior of criminally active persons;

a fairly complete picture of the system of antisocial and criminal ties in their environment;

identification of the microenvironment and the sphere of communication that stimulate antisocial and criminal behavior;

detection of hiding criminals;

study of the social and psychological character of persons, whose conduct is characterized by antisocial tendencies and risks of committing crimes.

Krylov \& Yakushyn (1984, pp. 132 - 133) in the framework of the issue under consideration, distinguish general (activities with extensive use of covert forces, means and methods in combination with transparent methods to identify, study, neutralize various negative factors and the elimination of conditions conducive to the perpetration of criminal acts by organizers and instigators) and individual prevention (a system of covert and public measures taken against specific individuals to prevent them from adversely affecting adolescents).

It should be noted that in the 80 's the topic of crime prevention in general and intentional homicide in particular began to be thoroughly studied by scientists of the former Soviet Union. In particular, we can highlight the works of Olieinik (1980) (Chapter II. Prevention and detection of crimes by criminal investigation); Lukashov (1982) (Section I. Organization and Tactics of Crime Prevention and Detection by 


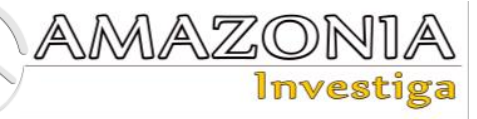

Criminal Investigators); Steinbrick \& Lukashov (1987); Honcharov \& Tykhonenko (1987) (Chapter 2. "Basic provisions of tactics of crime prevention by criminal investigation units") and others. The latter, among other things, emphasizes that "crime prevention is the task of all State agencies, public organizations and workers' groups. However, the largest amount of work on prevention (violent crime) by acting on specific criminogenic phenomena that give rise to crime is performed by law enforcement agencies and their criminal investigation units, which are part of them. Such work is organized and carried out with the use of special forces, means and methods, as well as in close cooperation with the police, other law enforcement agencies, public organizations, the administration of enterprises, organizations and institutions.

A significant contribution to the development of theoretical provisions of operational and search prevention was made, in particular, by Kozachenko (1991), who considered this problem within dissertation research. The author, in particular, argues that operational and search prevention is the system of operational control and preventive action against persons planning or preparing an offense, criminogenic situation and other anti-social phenomena, prevention of crimes planned or prepared, using operative and search forces, means and methods.

The proclamation of Ukraine's independence was the impetus for the further study and development of the fight against crime by the relevant police units in general and intentional homicides in particular, as the curve on the number of the latter was constantly growing. Indeed, the growth of crime was recorded in Ukraine in 1993 - 2003. For example, in 1992, 3,679 murders and assassinations were committed in the country, and in subsequent years this figure rose to 4,500 per year. In 2014, this figure was as high as 11,532 (Slovo I Dilo, 2020). Ukrainian scientists, based on the scientific achievements of their predecessors, as well as on positive foreign experience, have devoted (and are devoting) their research to various aspects of this issue.

In particular, Shendryk (2012) and Stashchak (2017) studied the organizational and tactical principles of the criminal police in general as a kind of operational and search activity force.

Many scientific works are also devoted to certain features of counteracting intentional homicides. In particular, Morozova's dissertation (2012) considers the peculiarities of the detection of serious and especially serious crimes of the past years by criminal investigation units.

In Chapter 3 "Prevention of Serial Crimes against the Life of a Person" in the manual "Countering Serial Crimes - Assault on Human Life" Horbachevskyi (2009, p. 129) identifies the following areas of prevention of these crimes: 1) identification and elimination of conditions that cause serial crimes against person's life (general prevention); 2) identification of persons, probable serial criminals, implementation of preventive influence for their re-orientation, in particular the tendency to give up criminal intentions (individual prevention).

Perepelytsia (2014, p. 351) studying the issue of combating serial killings committed by sex maniacs, argues that the organization of operational and search activities in this case has its own characteristics. It is determined by the fact that in addition to involving a psychologist as a specialist, for this category of crimes it is useful to create operational and search teams, the use of additional information and analytical support.

Zavorina (2019), researching the fight against intentional homicides committed by minors, notes that effective operational and investigative juvenile delinquency requires day-to-day research, analysis and evaluation of operational information that characterizes the structure and dynamics of minors. Monitoring of circumstances that contribute to the commission of murders by minors, namely: commission of a crime (crimes) by a minor earlier; committing crimes for which the minor did not bear responsibility; time, place, methods and circumstances of committing offenses; persons who involve adolescents in illegal activities; places of concentration of persons with antisocial views, connections with such persons, and persons of operational interest. That is, in order to effectively combat intentional homicides committed by juvenile by operative units, it is necessary to take into account such properties that are unique to children when assessing and analyzing the operational situation.

Lepekha \& Kondratiuk (2019, p. 122) on the basis of the implementation of operational and search characteristics of intentional homicides substantiate its influence on the choice of forms of covert counteraction to crimes. The authors argue that the search for primary information about the facts of the preparation of intentional homicides as a result of the application of 
operational (initiative) measures is ineffective. The work of a special entity introduced into an organized group or criminal organization to perform a special task of detecting criminal activity is justified in this direction.

Savka (2019), in turn, emphasizes that the proportion of intentional homicides committed on demand in the structure of murders ranges from $0.09 \%$ to $1.3 \%$, i.e. after the decrease in the number of intentional homicides in 2017 there is a tendency to their increase. The scientist claims that an effective way to counter committed on demand is to carry out covert, secret activities by law enforcement agencies. The most effective is the conduct of law enforcement control over the commission of a crime, which is one of the most complex and diverse in nature type of such procedural activities. Despite the fact that the Criminal Procedure Code of Ukraine has identified four forms of control over the commission of a crime, simulating a crime scene is more effective in counteracting intentional homicides committed on demand.

\section{Conclusion}

According to the Numbeo service that forms the Crime Index, Ukraine ranks $54^{\text {th }}$ in the world (out of 135) in terms of crime as of 2021. In Europe, according to this indicator, our country is in the $3^{\text {rd }}$ place after Belarus and France. In 2014, the number of crimes falling under the article "Intentional homicide" increased sharply - 11 532 recorded criminal offenses. Such a large number of the latter was connected with the tragic events that took place on the territory of Ukraine at that time - mass protests and shootings during the Euromaidan. In the following years, the number of murders gradually began to decrease: in 2015, 7993 criminal offenses were registered under this article, in 2016 - 5870 , in 2017 - 5029 , in 2018 - 5 535, in 2019 - 5 506; in 2020 - 3844 (Slovo I Dilo 2021).

As we can see from these data, the problem of preventing premeditated murders in Ukraine is more than relevant. In this article, we examined the development of scientific thought on this issue from ancient times to the present day, and determined that scientists who have studied the problems of operational and preventive prevention of this type of crime, primarily saw its purpose in identifying and eliminating conditions and circumstances. that contribute to its commission. Currently, this issue is also being actively studied, but most of the features of prevention of certain types of premeditated murder are being considered.

\section{References}

Abroskin, V., ed. (2020). Fundamentals of operational and investigative activities in Ukraine: a guide. Odessa: Publisher Bukaiev Vadym Viktorovich.

Alieksieiev, A. (1978). Operative and preventive supervision. Moscow: VNII MVD SSSR.

Chainey, S., \& Ratcliffe, J. (2005). GIS and Crime Mapping. London: Wiley. DOI: 10.1002/9781118685181

Cherkaskyi, I. (1928). Public court in UkraineRus in 16th -18 th centuries. Kyiv: Printing house of the Ukrainian Academy of Sciences.

Chysnikov, V. (2000). Legal origins of the criminal investigation service of Ukraine (historical aspect). Theory of operational and service activities of law enforcement agencies of Ukraine. Lviv: Lviv State University of Internal Affairs.

https://esu.com.ua/search_articles.php?id=9906 Dijk, J. \& De Waard, J. (1991). A twodimensional typology of crime prevention projects: With a bibliography. Criminal Justice Abstracts, 23(3), pp. 483-503

Honcharov, P., \& Tykhonenko, V. (1987). Prevention and detection of crimes by criminal investigation: a textbook for secondary special militia schools of the Ministry of Internal Affairs of the USSR. Moscow: Research and editorialpublishing department of MFYUZO at the Academy of the Ministry of Internal Affairs of the USSR.

Horbachevskyi, V. (2009). Countering Serial Crime - An Attack on Human Life: A Manual. Kyiv: UVPD HSh of the Ministry of Internal Affairs of Ukraine. https://www.naiau.kiev.ua/zagalnoakademichnikafedri/kafedra-kriminalnogoprocesu/vidannya-kafedri/perelik-drukovanihvidan/karpov.html

Kharytonov, E., Kharytonova, O., Kharytonova, T., Kolodin, D., \& Tolmachevska, Y. (2019). Human rights as the basic value of the concept of private law in modern Europe. Amazonia Investiga, 8(20), 477-485. Retrieved from https://amazoniainvestiga.info/index.php/amazo nia/article/view/177

Khyzhniak, Y., Khankevych, A., Shapovalenko, Y., Shkelebei, V., \& Yatsyk, T. (2021). Features of the prevention of intentional homicide by criminal police units". Amazonia Investiga, 10(38), pp. $212-218$. https://doi.org/10.34069/AI/2021.38.02.21.

https://amazoniainvestiga.info/index.php/amazo nia/article/view/1559/1552 


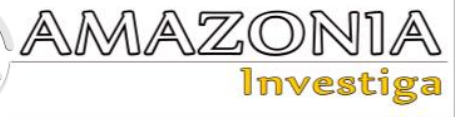

Kozachenko, I. (1991). Operational and investigative prevention (legal and organizational and tactical issues). Kiev: NIiRIO KVSH MVD SSSR.

Krylov, O., \& Yakushyn, N. (1984). On the concept of operational and investigative prevention and some socio-psychological aspects of the involvement of adolescents in criminal and other anti-social activities. Improving the organization and tactics of operational activities of the bodies of internal affairs. Omsk: Omsk higher militia school of the Ministry of Internal Affairs of the USSR.

Law No. 254k/96-VR, Constitution of Ukraine of June 28, 1996. Retrieved June 02, 2021 from https://zakon.rada.gov.ua/laws/show/254\%D0\% BA/96-\%D0\%B2\%D1\%80\#Text

Lepekha, O., \& Kondratiuk O. (2019). To the question of operational-investigative characteristic of intentional homicides and its influence on the selection of forms of crime covert counteraction. Social \& Legal Studios, Issue 3, No. 5, pp. 118-123.

Liekar, A. (1972). Crime prevention. Moscow: Legal Literature.

Lukashov, V. (1982). Operative and investigative activity of law enforcement agencies. Special part: textbook for students from socialist and developing countries studying in the universities of the Ministry of Internal Affairs of the USSR. Moscow: Academy of the Ministry of Internal Affairs of the USSR.https://a.mvd.ru/upload/site120/document _text/temp/_1458549023_905/2.pdf

Morozova, Ya. (2012). Disclosure of serious and especially serious crimes of the past years by the divisions of criminal investigation department. (PhD Dissertation) Lviv State University of Internal Affairs, Ukraine. http://www.irbisnbuv.gov.ua/cgi-

bin/irbis_nbuv/cgiirbis_64.exe?C21COM=S\&I2 $1 \mathrm{DBN}=\mathrm{EC} \& \mathrm{P} 21 \mathrm{DBN}=\mathrm{EC} \& \mathrm{~S} 21 \mathrm{FMT}=\mathrm{JwU} B \mathrm{~B} \&$ $\mathrm{S} 21 \mathrm{ALL}=\% 28 \% 3 \mathrm{C} . \% 3 \mathrm{EI} \% 3 \mathrm{D} \% 21 \mathrm{NBUV} \$ \% 3$ C. $\% 3 \mathrm{E} \% 29 \% 2 \mathrm{~A} \% 28 \% 3 \mathrm{C} . \% 3 \mathrm{EI} \% 3 \mathrm{D} \% 21 \mathrm{NBU}$ V\$\%3C.\%3E\%29\%2A\%28\%3C.\%3EI\%3D\%2 1NBUV\$\%3C.\%3E\%29\%2A\%28\%3C.\%3EU $\% 3 \mathrm{D} \% \mathrm{D} 0 \% \mathrm{~A} 5894.9 \% 284 \% \mathrm{D} 0 \% \mathrm{~A} 3 \% \mathrm{D} 0 \% 9 \mathrm{~A}$ $\% \mathrm{D} 0 \% \mathrm{~A} 0 \% 29311.2 \% 3 \mathrm{C} . \% 3 \mathrm{E} \% 29 \& \mathrm{Z} 21 \mathrm{ID}=\&$ S21SRW=AVHEAD \&S21SRD=DOWN\&S21S $\mathrm{TN}=1 \& \mathrm{~S} 21 \mathrm{REF}=10 \& \mathrm{~S} 21 \mathrm{CNR}=20$

Olieinik, P., ed. (1980). Operative and investigative activity of law enforcement agencies: textbook for the cadets of special secondary schools of militia. Omsk: Omsk higher militia school of militia of the Ministry of Internal Affairs of the USSR.

Ovchynskyi, S. (1982). Operational and investigative prevention: a lecture. Karaganda:
Karaganda higher school of the Ministry of Internal Affairs of the USSR.

Perepelytsia, M. (2014). Operational and investigative counteraction to serial murders committed by sexual maniacs (pp. 347 - 354). In: Kivalov, S. (ed.), Scientific works of the National University "Odessa Law Academy": collection of scientific works, Vol. 14. Odessa: Legal Literature.

Samoilov, V. (1982). Some aspects of operational and investigative activities as the process of cognition. The issues of improving the operational work of internal affairs agencies. Omsk: Omsk higher militia school of the Ministry of Internal Affairs of the USSR.

Savka, O. (2019). Imitation of assassination. (PhD Dissertation). Kharkiv National University of Internal Affairs, Ukraine.

Shendryk, V. (2012). Prevention of crimes by operative subdivisions of internal affairs agencies of Ukraine. (Doctoral Dissertation). Kharkiv National University of Internal Affairs, Ukraine.

Shteinbrik, B., \& Lukashov, V. (1987). Prevention and detection of crimes by criminal investigation divisions: textbook for students of higher educational institutions of the Ministry of Internal Affairs of the USSR. Moscow: Academy of the Ministry of Internal Affairs of the USSR. Slovo I Dilo (2020). Has Ukraine returned to the "disasters of the 90's": how has the crime rate changed since 1992? Retrieved June 02, 2021 from

https://www.slovoidilo.ua/2020/09/10/infografi $\mathrm{ka} /$ suspilstvo/chy-povernulasya-ukrayina-lyxi90-ti-yak-zminyvsya-riven-zlochynnosti-1992roku

Slovo I Dilo (2021). Crime in Ukraine: how the situation changed in 2013-2020. Retrieved June 02, $2021 \quad$ from https://www.slovoidilo.ua/2021/01/28/infografi $\mathrm{ka} /$ suspilstvo/zlochynnist-ukrayini-yakzminyuvalasya-sytuacziya-2013-2020-rokax Stashchak, M. (2017). Operational and investigative forms of crime prevention. (Doctoral Dissertation). Kharkiv National University of Internal Affairs, Ukraine.

Statehistory (2011) Instruction to the officers of detective departments of 1910. Retrieved June 02, 2021 from https://statehistory.ru/2087/Instruktsiya-chinamsysknykh-otdeleniy-ot-1910-g-/

Terliuk, I. (2006). History of the State and Law of Ukraine. (Pre-New Age): textbook. Kyiv: Atika.

United Nations Office on Drugs and Crime (2010). Handbook on the Crime Prevention Guidelines Making them work. Criminal justice handbook series. Vienna: United Nations 
publication. Retrieved June 02, 2021 from https://www.unodc.org/pdf/criminal_justice/Ha ndbook_on_Crime_Prevention_Guidelines__Making_them_work.pdf

US Department of Justice. (1963). Crime prevention bureaus in police departments international criminal police organization, 32nd general assembly session - Helsinki, Finland, August 1963. Retrieved June 02, 2021 from https://www.ojp.gov/ncjrs/virtual- library/abstracts/crime-prevention-bureauspolice-departments-international-criminal Zavorina, O. (2019). Operational and investigative counteraction to murders committed by minors. (PhD Dissertation). Kharkiv National University of Internal Affairs, Ukraine.

Zhohin, N., ed. (1962). Crime Prevention. Moskow: Hosiurizdat. 